\title{
Effects of a host tree on movement and distribution of winter geometrid moths (Lepidoptera): thickness of trunks and branches
}

\author{
Ján Kulfan ${ }^{1}$, Lenka Sarvašová ${ }^{1 *}$, Michal Parák ${ }^{1,2}$, Peter Zach $^{1}$ \\ 'Institute of Forest Ecology of the Slovak Academy of Sciences, L. Štúra 2, 96053 Zvolen, Slovak Republic \\ ${ }^{2}$ Present address: Banšelova 28, 82104 Bratislava, Slovak Republic
}

\begin{abstract}
Kulfan, J., Sarvašová, L., Parák, M., Zach, P., 2019. Effects of a host tree on movement and distribution of winter geometrid moths (Lepidoptera): thickness of trunks and branches. Folia Oecologica, 46: 83-90.

Adult moths from an ecological group of winter geometrid species look for trees where they copulate and females lay eggs. We investigated how tree trunk and lower branch thickness affects the occurrence of females on trunks and branches and how the density of females and tree trunk thickness affects the occurrence of males on trunks. The research was carried out in a xeric thermophilous oak forest in southern Slovakia (Central Europe) in the winter season 2014-2015. The moths were obtained from Quercus pubescens trees by sticky bands. Three autumn species Operophtera brumata, Erannis defoliaria, Alsophila aceraria and four spring species Agriopis leucophaearia, Agriopis marginaria, Apocheima hispidaria, Phigalia pilosaria were recorded. We have found out that females had not exclusively negative geotactic behaviour as they (except for the rare $P$. pilosaria) occurred also on lower branches. Tree trunk and lower branch thickness had a positive effect on abundance of females of the three most abundant species (A. leucophaearia, O. brumata, E. defoliaria) on trunks and lower branches. Tree trunk thickness had a positive effect on density of the females of $A$. leucophaearia on trunks but not on $O$. brumata and E. defoliaria. The abundance of the males of $O$. brumata, E. defoliaria and A. leucophaearia on trunks was positively affected by tree trunk thickness and the density of their females.
\end{abstract}

Key words

behaviour, forest pests, phytophagous insects

\section{Introduction}

Species from an ecological group of winter geometrid moths (Geometridae) (WAHLBERG et al., 2010) belong to the most important forest defoliators. The adults occur in the cold part of year (late autumn or early spring) and their brachypterous females are incapable of flight (WAHLBERG et al., 2010). Their caterpillars are mostly polyphagous and form an important part of spring caterpillar assemblages (PATOČKA et al., 1999). Operophtera brumata is a well known winter moth species and has been the object of many ecological and behavioral studies (CUMING, 1961; Mrkva, 1968; EdLand, 1971; Holliday, 1977; TikKanEN et al., 2006; ELKINTON et al., 2014). Other winter moth species, although relatively abundant in Central Europe (MACEK et al., 2012), have been much less studied.

After dusk, the virgin females of $O$. brumata climb tree trunks upwards (negative geotaxis) where they copulate. Then they continue crawling up trunks and lay their eggs in tree crowns (MrKVA, 1968; GRAF et al., 1995; VAN Dongen et al., 1998). The eggs are placed on branches (Mrkva, 1968; Holliday, 1977; NiLSSEN et al., 2007;

*Corresponding author:

e-mail: sarvasova@ife.sk 
TENOw et al., 2007) and sporadically on trunks (MrKva, 1968; WATT et al., 1992). MRKVA (1968) discovered that on tall oaks the females preferred branches in the upper parts of trees. Also GrAF et al. (1995) described the same preference on apple and cherry trees, although they recorded a considerable amount of females crawling on horizontal branches. The winged males fly around trees using vision and actively search for pheromone-emitting females (Mrkva, 1968; Van Dongen et al., 1994, 1998; MeyerRochOW and LAU, 2008). We have not found similar detailed information about the behaviour of other winter geometrid species in the literature.

The aim of this study is to address the following questions: (1) What is the composition of assemblages of winter geometrid moths in a Central European xeric thermophilous oak forest? (2) Are the brachypterous females of winter moths negatively geotactic on low branched oaks? (3) How does tree trunk and lower branch thickness affect the total number of females on trunks and branches? (4) How does tree trunk thickness affect the density of females on trunks? (5) How do the density of females and tree trunk thickness affect the abundance of males on trunks?

We expected several species of winter moths in late autumn and early winter (referred to as autumn species in this study) and several species in late winter and early spring (referred to as spring species in this study) (cf. PATOČKA et al., 1999; РАTOČKA and Kulfan, 2009; MACEK et al., 2012). We supposed that all recorded species of this group of moths would have the same or similar behaviour because of specific winter conditions. We expected that some females could leave a tree trunk and climb branches in the lower parts of a host tree. This is also related to the distribution of eggs (MORAVSKAJA, 1960; GrAF et al., 1995). The total number of females could be higher on thick tree trunks and branches than on thin ones (Mrkva, 1968; Connell, 2013). Density of females could be higher on thick tree trunks than on thin ones if they are supposed to orient themselves by vision and to prefer thick tree trunks (cf. GRISON and SILVESTRE DE SACY, 1954; Graf et al., 1995; Meyer-Rochow and LaU, 2008). Besides tree trunk thickness, abundance of males could also be affected by the density of pheromone-emitting females.

\section{Materials and methods}

\section{Characteristics of the locality}

The research was carried out in the southern part of the Western Carpathians, in the Krupinská planina Plateau in Slovakia, Central Europe (48 $10^{\circ} 0.19$ 'N, 1859'46.08'E), at the altitude between 265 and $330 \mathrm{~m}$ asl. The area belongs to a warm climatic region with mean annual air temperature $8-9{ }^{\circ} \mathrm{C}$ and mean annual precipitation $600-700$ $\mathrm{mm}$ (ANONYMUS, 2015b). Data were collected in a xeric thermophilous oak forest dominated by pubescent oak (Quercus pubescens) and Turkey oak (Q. cerris). Other tree species such as Acer campestre L., A. tataricum L., Tilia spp., Sorbus torminalis (L.) Crantz., Crataegus spp., Carpinus betulus L., Pyrus spp. and Ulmus spp. were infrequent and less abundant. The average height of oaks between $8-12 \mathrm{~m}$ is a result of warm and dry climate and dry shallow stony soils in the area. The age of trees is about 70 years and the average tree diameter at breast height is 20.4 $\mathrm{cm}$. Surrounding landscape is managed extensively (sheep pastures, vineyards, fruit orchards, gardens) but the forest is without active management recently.

\section{Data collecting}

Forty-five trees of Quercus pubescens with a first lower branch growing from the trunk in an approximately right angle $\left(90^{\circ}\right)$ were selected. At each tree, trunk thickness (diameter) at breast height (DBH) and lower branch circumference at a distance of $10 \mathrm{~cm}$ from the trunk were measured. The range of distances of the lower branches from the ground surface was 55-200 cm. Moths were collected on the aforementioned 45 trees using sticky bands (HÉBERT and St-Antoine, 1999) (a product by Bio Plantella). One sticky band was installed on the first lower branch of the trees at a distance of $10 \mathrm{~cm}$ from the trunk. Another sticky band was placed on the trunk above the marked branch (Fig. 1). To avoid removal of glued moths by predators (mainly birds) we installed aviary mesh around all sticky bands. Adult moths were collected in the cold period from $20^{\text {th }}$ November 2014 to $10^{\text {th }}$ April 2015. During that time sticky bands were regularly controlled and replaced with fresh ones in order to avoid their saturation by moth males. After removing sticky bands with glued moths from trees we wrapped them into plastic wrap which enabled their easy handling, transport and storage in a refrigerator. Then the moths were determined and counted in a laboratory. We used a stereo microscope and identification guides MACEK et al. (2012), RENNWALd and RodELAND (2002), Jonko (2014) and MAZzEI et al. (1999). The nomenclature follows PAstoráLIs et al. (2013).

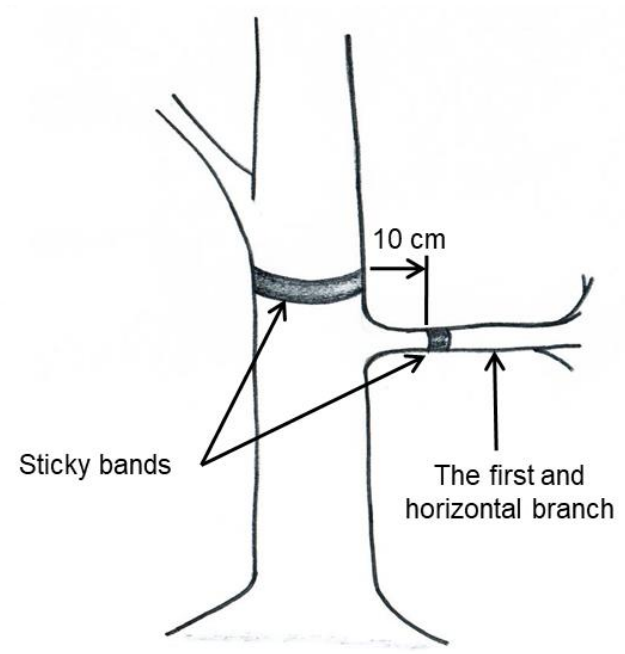

Fig. 1. Collecting of moths by sticky band method. 


\section{Statistical analysis}

Moth abundance and density were modelled as a function of DBH and in case of males also as a function of the density of females. The abundance of moths was overdispersed, therefore, negative binomial model approach with log or square root link was used. In case of moth density models an offset variable, circumference of tree trunk at breast height, was incorporated. All analyses and figures were calculated in R (R CORE TEAM, 2018) using mainly MASS (VENABles and RIPLEY, 2002) and visreg (BREHENY and BuRCHETT, 2017) libraries.

\section{Results}

Using sticky bands, we recorded seven species in two time periods. Species caught in November and December 2014 ( 6,075 specimens) belonged to the group of autumn species and species caught in January-April 2015 (15,617 specimens) belonged to the group of spring species (Table 1). Among autumn species $O$. brumata and E. defoliaria dominated while among spring species only A. leucophaearia was dominant (Table 1). There were less females than males caught on sticky bands. The females of each autumn species (O. brumata, E. defoliaria, A. aceraria) comprised about $1 / 10$ of all recorded specimens. Proportion of females of spring species was higher; the females of A. leucophaearia and A. marginaria comprised about $1 / 6$ and those of $A$. hispidaria comprised more than $1 / 5$ of recorded specimens (Fig. 2). Phigalia pilosaria (not shown in the Fig. 2) was rare; only four females and no males were recorded on tree trunks.

Table 1. Dominance of recorded winter geometrid species in a xeric thermophilous oak forest in southern Slovakia

\begin{tabular}{lc}
\hline Autumn species & Dominance (\%) \\
\hline $\begin{array}{l}\text { Operophtera brumata } \\
\text { (Linnaeus, 1758) }\end{array}$ & 75.06 \\
$\begin{array}{l}\text { Erannis defoliaria } \\
\text { (Clerck, 1759) }\end{array}$ & 23.01 \\
$\begin{array}{l}\text { Alsophila aceraria } \\
\text { (Denis et Schiffermüller, 1775) }\end{array}$ & 1.93 \\
\hline Spring species & \\
\hline $\begin{array}{l}\text { Agriopis leucophaearia } \\
\text { (Denis et Schiffermüller, 1775) }\end{array}$ & 98.00 \\
$\begin{array}{l}\text { Agriopis marginaria } \\
\text { (Fabricius, 1776) } \\
\text { Apocheima hispidaria } \\
\text { (Denis et Schiffermüller, 1775) }\end{array}$ & 1.74 \\
$\begin{array}{l}\text { Phigalia pilosaria } \\
\text { (Denis et Schiffermüller, 1775) }\end{array}$ & 0.23 \\
\hline
\end{tabular}

The nomenclature by PASTORÁLIS et al. (2013) is used.
All species occurred on tree trunks and six species (O. brumata, E. defoliaria, A. aceraria, A. leucophaearia, A. marginaria, A. hispidaria) were also caught on the lowest branches. Nevertheless, most specimens were recorded on trunks above the first branches. Among the recorded species, males of $O$. brumata and both sexes of $A$. hispidaria occurred on branches most frequently (Fig. 2).

Tree trunk thickness (DBH) and branch thickness had a positive effect on female abundances of the three most abundant species - O. brumata, E. defoliaria and A. leucophaearia (Figs 3, 4) ( $p<0.05$ for all three species).

Density (number of specimens per $2 \mathrm{~cm}$ of tree trunk circumference at $1.3 \mathrm{~m}$ above ground level) of females was affected positively by tree trunk thickness only in the spring species A. leucophaearia ( $p=0.016$ ) (Fig. 5, c). Tree trunk thickness had no effect on density of females of the two most abundant autumn species $-O$. brumata and E. defoliaria (Fig. 5, a-b).

Abundance of males of the three most abundant species recorded (O. brumata, E. defoliaria, A. leucophaearia) was affected positively by tree trunk thickness ( $p<$ 0.05 for all three species) and by density of their females $(p<0.05$ for all three species; Fig. 6, a-c).

\section{Discussion}

Adult geometrid moths collected from autumn to spring in season 2014-2015 represented the majority of winter moth species living on oaks in Central Europe (KulfaN, 1992; РАTOČKA et al., 1999; РАTOČKA and Kulfan, 2009; MACEK et al., 2012). Among recorded autumn species $O$. brumata and E. defoliaria dominated markedly. These two geometrid moths belong to important defoliators with a tendency toward population outbreaks and high possibility of causing total defoliation (MrKva, 1968; CiORNEI and Mihalache, 1998; PATOČKa et al., 1999; ZúBRIK, 2007; NeţoIU et al., 2014) and thus, their dominance in the studied oak forest stand was expected. Among spring species A. leucophaearia had the highest prevalence. Although it is abundant in Central Europe (PATOČKA, 1954; SzABó et al., 2007; AnONymus, 2015a), it has been omitted in forestry practice so far. The rest of the recorded species had low abundances although some of them can be numerous in some years or regions (cf. CsóKA, 1998; SzABó et al., 2007; NeŢOIU et al., 2014).

In the obtained samples females of all species comprised less than one quarter of all recorded specimens (except the rare P. pilosaria). This disproportion may be caused by different mobility between sexes. Males able to fly move easier within a tree and between trees. We suppose, therefore, that they stick easier on sticky bands. On the contrary, brachypterous females have limited motion as they are only able to walk, thus, less of them will stick on sticky bands. Besides that, males are attracted by female pheromones (SzÖCZ and TóTH, 1978; RoELOFs et al., 1982; SzÖCZ et al., 1993; VAN Dongen et al., 1998; MeYer-Rochow and LaU, 2008) and thus, females caught 


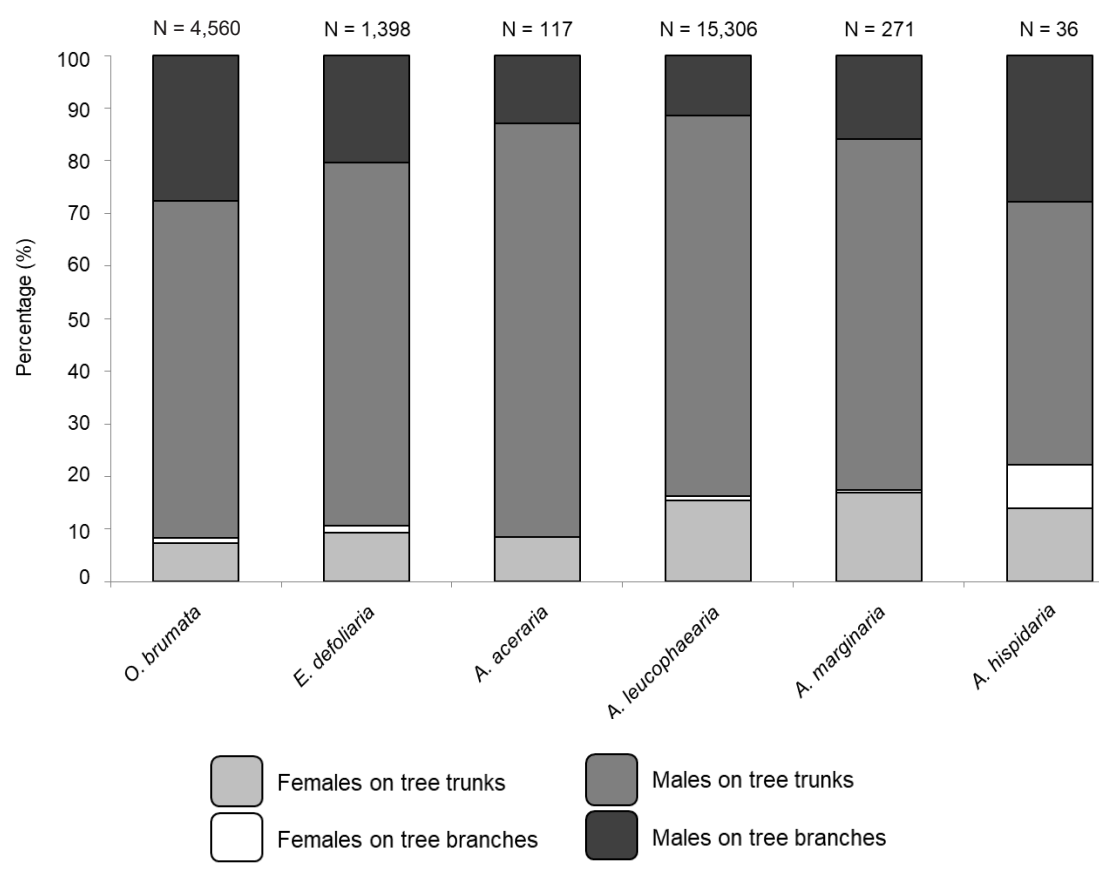

Fig. 2. Males and females of winter geometrid species caught on sticky bands on tree trunks and lower branches.

(a)

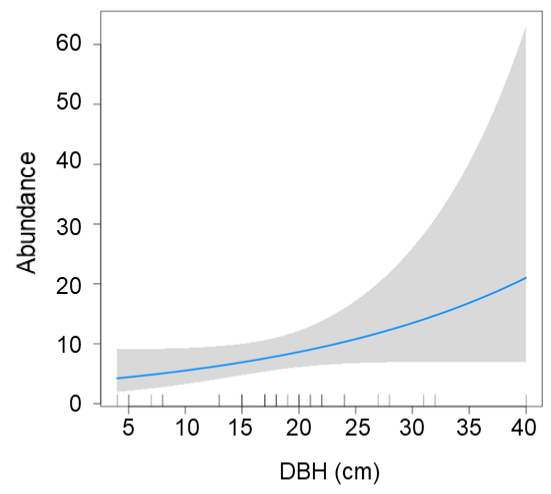

(b)

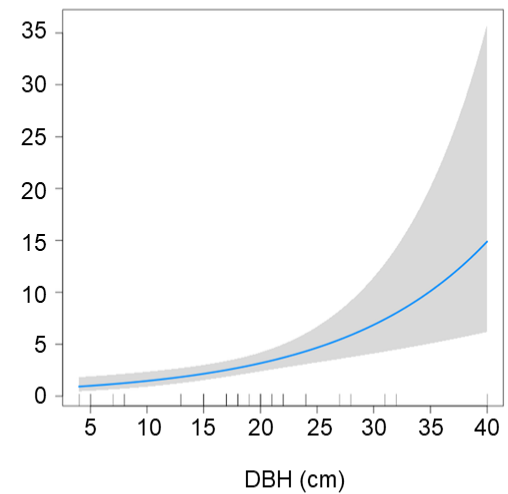

(c)

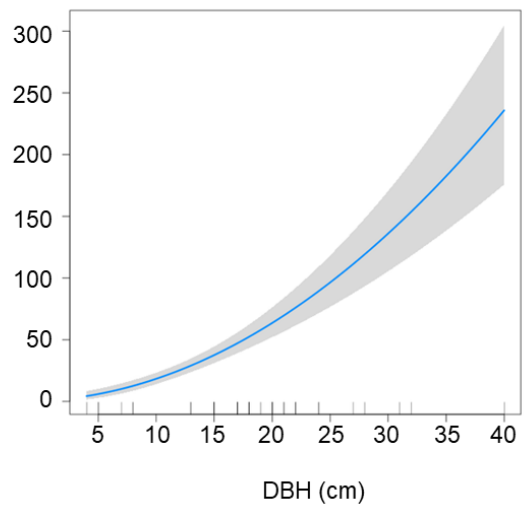

Fig. 3. Abundances of females of a) O. brumata $\left(p=0.0411 ; X^{2}=4.174\right)$, b) E. defoliaria $\left(p<0.0001 ; X^{2}=21.165\right)$ and c) A. leucophaearia $\left(p<0.0001 ; X^{2}=47.356\right)$ on tree trunks depending on tree trunk thickness (DBH).

(a)

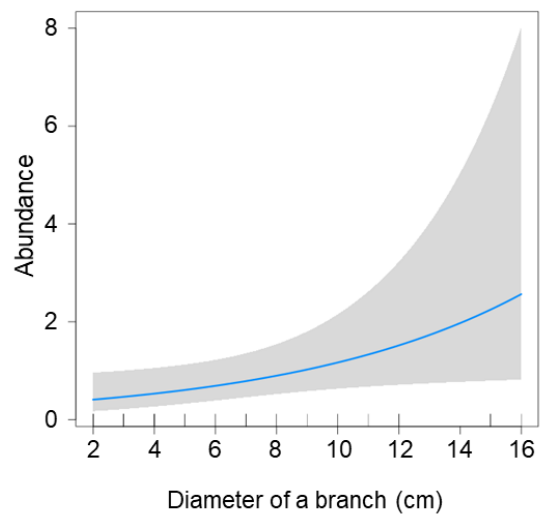

(b)

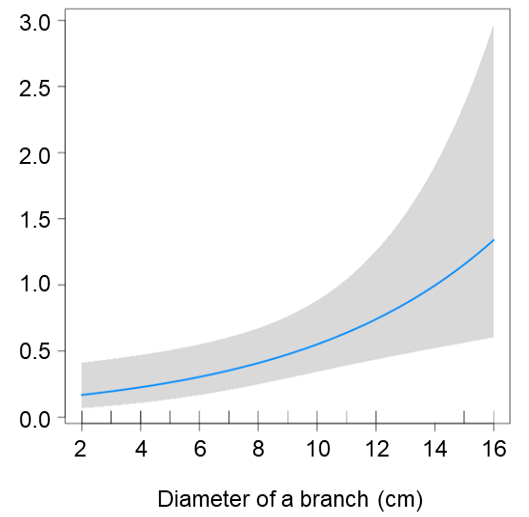

(c)

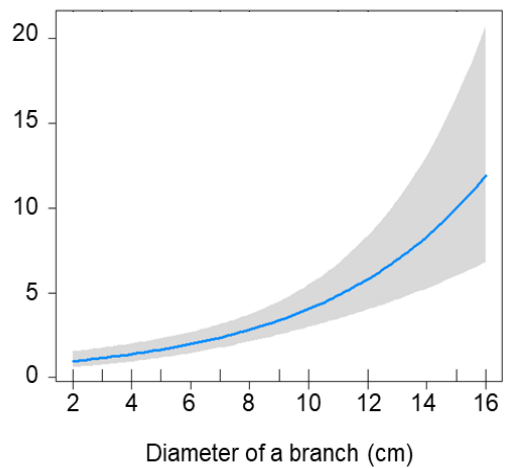

Fig. 4. Abundances of females of a) O. brumata $\left(p=0.0196 ; X^{2}=5.449\right)$, b) E. defoliaria $\left(p=0.0034 ; X^{2}=8.573\right)$ and c) A. leucophaearia $\left(p<0.0001 ; X^{2}=33.254\right)$ on lower branches depending on the thickness of these branches. 
(a)

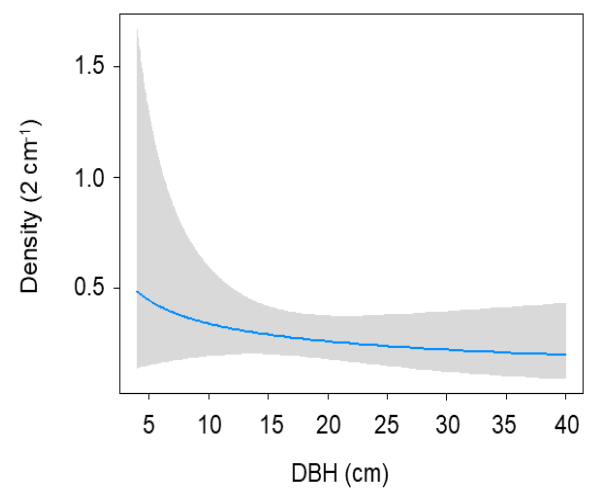

(b)

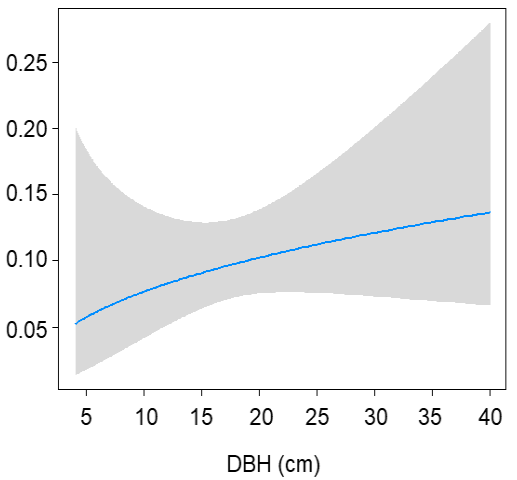

(c)

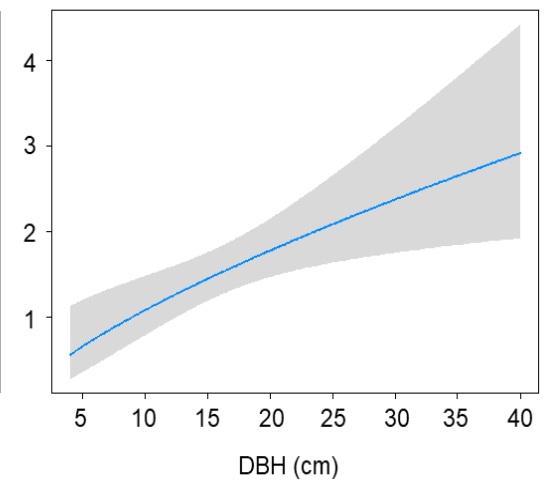

Fig. 5. Density (number of specimens per $2 \mathrm{~cm}$ of tree trunk circumference at $1.3 \mathrm{~m}$ above ground level) of females of a) O. brumata $\left(p=0.341 ; X^{2}=1.060\right)$, b) E. defoliaria $\left(p=0.329 ; X^{2}=1.225\right)$

and c) A. leucophaearia ( $\left.p=0.016 ; X^{2}=7.311\right)$ on tree trunks depending on the thickness of these trunks at $1.3 \mathrm{~m}$ above ground level.

on sticky bands could attract males continuously resulting in large numbers of captured males.

Specimens of both sexes occurred both on tree trunks and first lower horizontal tree branches (except A. aceraria). Tree trunk and lower branch thickness had a positive effect on the abundance of females of the three most abundant species - O. brumata, E. defoliaria and A. leucophaearia. This confirms results obtained on $O$. brumata by MrKva (1968) and ConNell (2013). This dependence had not been known before in the other two species. According to PARÁK (2015) tree trunk thickness measured at a place of contact with ground had affected female density of $O$. brumata and A. leucophaearia positively.

Females of $O$. brumata orient themselves in space by vision (Grison and Silvestre DE SACY, 1954; GrAF et al., 1995; MeYer-Rochow and LaU, 2008). At the time of their eclosion from pupae and search for places for oviposition, the majority of trees and bushes are bare/without foliage. Thus, females do not elect a host plant (CONNELL, 2013) and climb every vertical object in their vicinity (Grison and Silvestre De SaCy, 1954; Graf et al., 1995). Despite the fact that the visual orientation has not been studied yet in the rest of the recorded species, we suppose, based on our results, that the females of E. defoliaria and A. leucophaearia orient themselves by vision, too, and climb all vertical objects, so they can colonise any tree in their vicinity.

In our study, about $1 / 10$ of females of $O$. brumata and $E$. defoliaria, and $6 \%$ of females of $A$. leucophaearia were recorded on horizontal branches (Fig. 2). This means that females climbing tree trunks are not exclusively negatively geotactic and could perceive protruding branches in front of them. It suggests possible visual orientation in determining direction of their movement. Distribution of eggs of $O$. brumata (and therefore movement of females) differs between tree species (MoravSKAJA, 1960; MrKVA, 1968; Graf et al., 1995). MrKva (1968) explained this contrast as a result of different bark structure between tree species. Another reason may be host plant architecture. For example, MrKva (1968) reported that females of $O$. brumata almost avoided lower lateral branches on about
$25 \mathrm{~m}$ tall trees of Quercus robur. In our study, some females changed direction from trunks to the first horizontal branches on low branched trees of $Q$. pubescens with similar bark. As many males were recorded on the first horizontal branches (Fig. 2), we suppose that the females reaching these branches can be fertilized there as well (or they are already fertilized) and subsequently oviposit. There is a variability of sources in tree crowns (shelters and food sources) (Gripenberg and RosLin, 2005) and therefore behaviour of females like this provides their offspring a good chance to find appropriate food sources of high quality.

The density of females was positively affected by tree trunk thickness only in the spring species A. leucophaearia. This factor had no effect on both autumn species $O$. brumata and $E$. defoliaria. The reasons are unclear. One explanation could be that $A$. leucophaearia has different visual perception in comparison with $O$. brumata and $E$. defoliaria and its females are more attracted by thick trunks. Another explanation could be larger stocks of pupae in the ground below thicker trees. Revealing the causes behind this requires further research.

Tree trunk thickness had also a positive effect on abundance of males in the three most abundant species (O. brumata, E. defoliaria and A. leucophaearia). This result suggests importance of vision (visual orientation) of males as MeYER-Rochow and LAU (2008) had shown for O. brumata. Besides this factor, female density affected male abundance positively, too. Like on branches, females attracted males by emitting pheromones on tree trunks (SzÖCZ and TóTH, 1978; RoELoFs et al., 1982; Szöcz et al., 1993).

\section{Acknowledgements}

We thank Peter Tuček and Milan Mikuš for technical assistance. The staff of the Plášt'ovce forestry station and private owners supported field studies. The study was supported by the grants VEGA No 2/0012/17, VEGA No 2/0032/19 and APVV No 15-0348. 
(a)

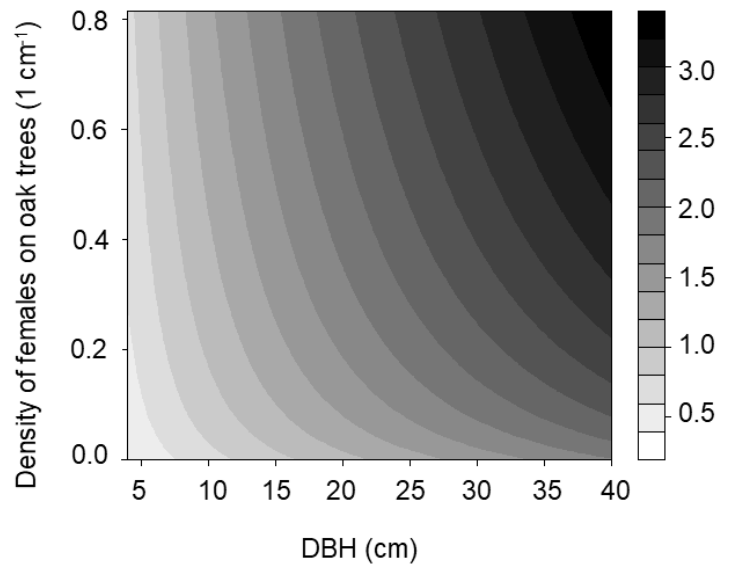

(b)

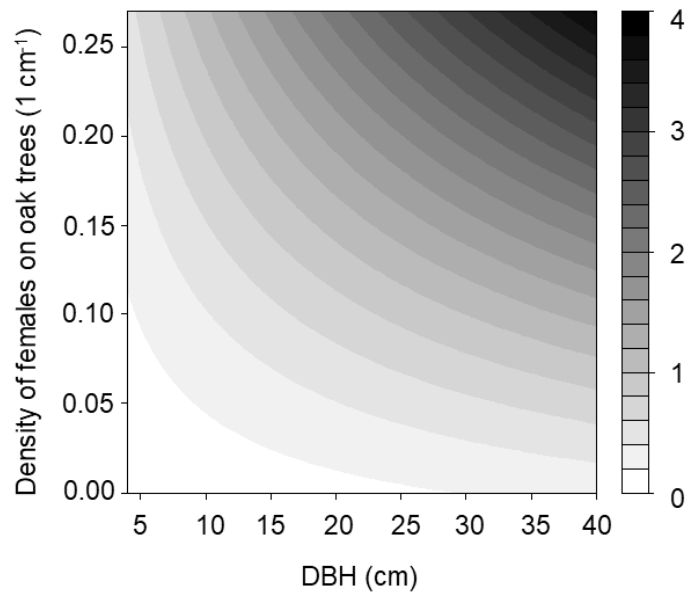

(c)

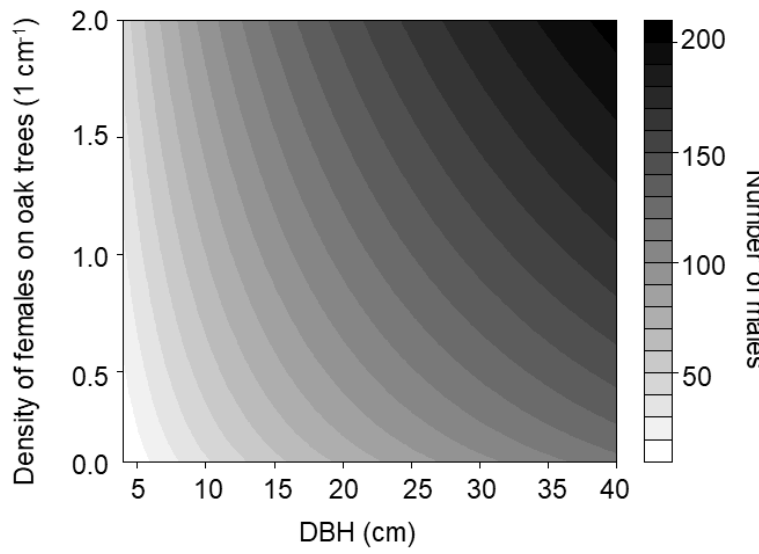

Fig. 6. Abundance of males on trunks of oak trees of a) O. brumata (factor female density: $p<0.0001$, $X^{2}=16.2600$; factor trunk thickness: $p=0.0176$,

$\left.X^{2}=5.6367\right)$, b) E. defoliaria (factor female density: $p=0.0118, X^{2}=6.3350$; factor trunk thickness: $p=0.0138$, $X^{2}=6.0586$ ) and c) A. leucophaearia (factor female density: $p=0.0120, X^{2}=6.3060$; factor trunk thickness: $p<0.0001$, $X^{2}=51.0420$ ) depending on tree trunk thickness and density of their females (number of specimens per $1 \mathrm{~cm}$ of tree trunk circumference at $1.3 \mathrm{~m}$ above ground level).

\section{References}

AnOnymus, 2015a. Atlas škodcov lesa [Atlas of forest pests]. Banská Štiavnica: Lesnícka ochranárska služba. [cit. 2018-09-25]. http://www.skodcoviadrevin.sk/ skodca/piadivka-osikova

AnONYmus, 2015b. Klimatický atlas Slovenska. Climate atlas of Slovakia. Bratislava: Slovenský hydrometeorologický ústav. $132 \mathrm{p}$.

BREHENY, P., BURCHETT, W., 2017. Visualization of regression models using visreg. The R Journal, 9: 56-71.

Ciornei, C., Mihalache, G., 1998. Integrated control of species of Geometridae in oak forests of Romania. In McManus, M.L. and Liebhold, A.M. (eds). Population dynamics, impacts, and integrated management of forest defoliating insects. Proceedings. Banská Štiavnica, Slovak Republic, August 18-23, 1996.USDA Forest Service General Technical Report NE, 247. Radnor, Pennsylvania:USDA Forest Service, Northeastern Research Station, p. 222-229.

Connell, J., 2013. Wirtsbaumwahl durch aufbaumende Weibchen des Kleinen Frostspanners, Operophtera brumata L.: Ergebnisse einer vierjährigen Studie in Wien [Host-tree selection of females of the Winter Moth, Operophtera brumata L.: results of a four-year study in Vienna]. Forstschutz Aktuell, 57 (58): 22-26.

CsóKA, G., 1998. Oak defoliating insects in Hungary. In McManus, M.L., Liebhold, A.M. (eds). Population dynamics, impacts, and integrated management of forest defoliating insects. Proceedings. Banská Štiavnica, Slovak Republic, August 18-23, 1996. USDA Forest Service General Technical Report NE, 247. Radnor, Pennsylvania: USDA Forest Service, Northeastern Research Station, p. 334-335.

Cuming, F.G., 1961. The distribution, life history, and economic importance of the Winter Moth, Operophtera brumata (L.) (Lepidoptera, Geometridae) in Nova Scotia. The Canadian Entomologist, 93: 135-142. https:// doi.org/10.4039/Ent93135-2

EDLAND, T., 1971. Wind dispersal of the winter moth larvae Operophtera brumata L. (Lep.,Geometridae) and its relevance to control measures. Norsk Entomoligisk Tidsskrift, 18 (2): 103-105.

Elkinton, J.S., Liebhold, A., Boettner, G.H., Sremac, M., 2014. Invasion spread of Operophtera brumata in northeastern United States and hybridization with O. bruceata. Biological Invasions, 16: 2263-2272. https:// doi.org/10.1007/s10530-014-0662-9

Graf, B., Borer, F., Höpli, H.U., Hohn, H., Dorn, S., 1995. The winter moth Operophtera brumata L. (Lep., Geometridae) on apple and cherry: spatial and temporal aspects of recolonization in autumn. Journal of Applied Entomology, 119: 295-301. https://doi. org/10.1111/j.1439-0418.1995.tb01289.x

GriPenBerG, S., Roslin, T., 2005. Host plants as islands: Resource quality and spatial setting as determinants of insect distribution. Annales Zoologici Fennici, 42: 335-345.

Grison, P., Silvestre de SACy, R., 1954. Déplacement orienté de la femelle de cheimatobie (Operophtera brumata L.) [Oriented movement of the females of the 
Winter Moth (Operophtera brumata L.)]. Bulletin de la Societé Entomologique de France, 59: 151-154.

HÉBert, C., St-Antoine, L., 1999. Oviposition trap to sample eggs of Operophtera bruceata (Lepidoptera: Geometridae) and other wingless geometrid species The Canadian Entomologist, 131: 557-565. https:// doi.org/10.4039/Ent131557-4

Holliday, N.J., 1977. Population ecology of winter moth (Operophtera brumata) on apple in relation to larval dispersal and time of bud burst. Journal of Applied Ecology, 14 (3): 803-813. doi: 10.2307/2402812

JoNKO, C., 2014. European butterflies and moths. Updated 2015-10-09. [cit. 2015-12-09]. http://www.lepidoptera.eu

Kulfan, J., 1992. Zur Struktur und Saisondynamik von Raupenzönosen (Lepidoptera) an Eichen [On structure and seasonal dynamics of caterpillar assemblages (Lepidoptera) on oaks]. Biologia, Bratislava, 47: 653661.

MaceK, J., ProcházKa, J., Traxler, L., 2012. Motýli a housenky středni Evropy. Noční motýli III. - píd'alkovití [Butterflies, moths and caterpillars of Central Europe. Moths III. — Geometrids]. Praha: Academia. 424 p.

Mazzei, P., Morel, D., Panfili, R., 1999. Moths and butterflies of Europe and North Africa. [cit. 2015-12-06]. http://www.leps.it/

Meyer-Rochow, V.B., Lau, T.F., 2008. Sexual dimorphism in the compound eye of the moth Operophtera brumata (Lepidoptera, Geometridae). Invertebrate Biology, 127 (2): 201-216. https://doi.org/10.1111/ j.1744-7410.2008.00131.x

MoRAVSKAJA,A.C., 1960. Biologia i někotoryje zakonoměrnosti izměněnija čislěnnosti zimnějí pjaděnici (Operophtera brumata L.) [Biology and some patterns of changes of abundance of the Winter Moth (Operophtera brumata L.)]. Trudy Instituta Lesa, 48: 59-101.

MrKvA, R., 1968. Bionomie píd'alky podzimní (Operophtera brumata L.) - motýl a vajíčko [Bionomy of the Winter Moth (Operophtera brumata L.) -moth and egg]. Acta Universitatis Agriculturae (Brno). Series C, 37: 223-246.

Neţoiu, C., Tomescu, R., Vladescu, D., Aldea, D.I., BuZATU, A., 2014. Evolution of infestations loopermoth (Geometridae) in oak forests from Romania. Annals of the University of Craiova - Agriculture, Montanology. Cadastre Series, 44 (1): 301-310.

Nilssen, A.C., Tenow, O., Bylund, H., 2007. Waves and synchrony in Epirrita autumnata/Operophtera brumata outbreaks. II. Sunspot activity cannot explain cyclic outbreaks. Journal of Animal Ecology, 76 (2): 269275. https://doi.org/10.4039/Ent131557-4

PARÁK, M., 2015. Reakcie vybraných skupín motýlov na meniacu sa štruktúru lesa [Reactions of selected group of moths (Lepidoptera) to changing forest structure]. $\mathrm{PhD}$ thesis. Zvolen: Institute of Forest Ecology of the Slovak Academy of Sciences, Faculty of Ecology and Environmental Sciences, Technical University in Zvolen. 92 p.

Pastorális, G., Kalivoda, H., Panigaj, L., 2013. Zoznam motýl'ov (Lepidoptera) zistených na Slovensku
[Checklist of Lepidoptera recorded in Slovakia]. Folia Faunistica Slovaca, 18: 101-232.

PATOČKa, J., 1954. Húsenice na duboch v ČSR [Caterpillars on oaks in the Czechoslovak Republic]. Bratislava: Štátne pôdohospodárske nakladatel'stvo. 264 p.

PATOČKa, J., KRIŠTín, A., Kulfan, J., ZACH, P. (eds), 1999. Die Eichenschädlinge und ihre Feinde [Oak pests and their enemies]. Zvolen: Institut für Waldökologie der SAW. 396 p.

PATOČKA, J., Kulfan, J., 2009. Lepidoptera of Slovakia: bionomics and ecology. Bratislava: Veda. $312 \mathrm{p}$.

R CORE TEAM, 2018. R: a language and environment for statistical computing. Vienna, Austria: R Foundation for Statistical Computing. [cit. 2018-12-10]. https:// www.R-project.org/

RENNwald, E., Rodeland, J., 2002. Lepiforum: Bestimmung von Schmetterlingen (Lepidoptera) und ihren Präimaginalstadien [Lepiforum: identification of butterflies and moths (Lepidoptera) and their preimaginal stages]. Updated 2018-04-16. [cit. 2015-06-05]. http:// www.lepiforum.de

Roelofs, W.L., Hill, A.S., Linn, C.E., Meinwald, J., Jain, S.C., Herbert, H.J., Smith, R.F., 1982. Sex pheromone of the winter moth, a geometrid with unusually low temperature precopulatory responses. $\mathrm{Sci}$ ence. New Series, 217 (4560): 657-659. doi: 10.1126/ science. 217.4560 .657

Szabó, S., Ámyas, E.M., Tóthmérész, B., VARGa, Z., 2007. Long-term light trap study on the macro-moth (Lepidoptera: Macroheterocera) fauna of the Aggtelek National Park. Acta Zoologica Academiae Scientiarum Hungaricae, 53 (3): 257-269.

Szöcz, G., TóтH, M., 1978. Evidence and extraction of a female sex pheromone from the winter moth Operophthera brumata (L.). Acta Phytopatologica. Academia Scientiarum Hungaricae, 13: 213-217.

Szöcz, G., Tóth, M., Francke, W., Schmidt, F., PhilipP, P., König, W.A., Mori, K., Hansson, B.S., LöFstedt, C., 1993. Species discrimination in five species of winter-flying geometrids (Lepidoptera) based on chirality of semiochemicals and flight season. Journal of Chemical Ecology, 19 (11): 2721-2735. https://doi. org/10.1007/BF00980703

Tenow, O., Nilssen, A.C., Bylund, H., Hogstad, O., 2007. Waves and synchrony in Epirrita autumnata/ Operophtera brumata outbreaks. I. Lagged synchrony: regionally, locally and among species. Journal of Animal Ecology, 76 (2): 258-268. https://doi. org/10.1111/j.1365-2656.2006.01204.x

Tikkanen, O.-P., Woodcock, B., Watt, A., Lock, K., 2006. Are polyphagous geometrid moths with flightless females adapted to budburst phenology of local host species? Oikos, 112 (1): 83-90. https://doi. org/10.1111/j.0030-1299.2006.13855.x

Van Dongen, S., Backeljau, T., Matthysen, E., DHONDT, A.A., 1994. Effects of forest fragmentation on the population structure of the winter moth Operophtera brumata L.(Lepidoptera, Geometridae). Acta Oecologica, 15 (2): 193-206.

Van Dongen, S., Matthysen, E., Sprengers, E., 
DHONDT, A.A., 1998. Mate selection by male Winter Moths Operophtera brumata (Lepidoptera, Geometrldae): adaptive male choice or female control? Behaviour, 135 (1): 29-42. https://doi.org/10.1046/j.13652540.1998.00278.x

Venables, W.N., RIPLEY, B.D., 2002. Modern applied statistics with S. Fourth edition. New York: Springer. 498 p.

WAHLbERG, N., SNÄLl, N., ViIdAlepP, J., RUOHOMÄKI, K., TAmmaru, T., 2010. The evolution of female flightlessness among Ennominae of the Holarctic forest zone (Lepidoptera, Geometridae). Molecular Phylogenetics and Evolution, 55 (3): 929-938. https://doi. org/10.1016/j.ympev.2010.01.025

Watt, A.D., Evans, R., Varley, T., 1992. The egg laying behaviour of a native insect, the winter moth Operoph- tera brumata (L.) (Lep., Geometridae), on an introduced tree species, Sitka spruce Picea sitchensis. Journal of Applied Entomology, 114 (1-5): 1-4. https://doi. org/10.1111/j.1439-0418.1992.tb01089.x

ZúBRIK, M., 2007. Listožravý a cicavý hmyz [Leafeating and sucking insects]. In GuBKA, A., KunCA, A., KonôpKa, B., KonôPKA, J., LeOntovyČ, R., Longauerová, V., Nikolov, C., Novotný, J., Vakula, J., VARÍNSKY, J., ZÚBRIK, M. Škodlivé činitele lesných drevín a ochrana pred nimi [Agents harmful to forest tree species and related protection measures]. Zvolen: Národné lesnícke centrum, p. 101-134.

Received July 8, 2019 Accepted August 21, 2019 